\title{
NEPALI MIGRANTS POLITICAL ACTIVISMS IN INDIA AND THEIR ENGAGEMENT WITH HOMELAND
}

Keshav Bashyal

\begin{abstract}
Dominance of research on Nepalis migration to India is consideres as 'for livelihood', 'passage of rites', 'taken for granted', more importantly 'tradition' or 'Kamaune' for majority of Nepalis. Nepal is an oldest nation-state of South Asia and its democracy had been, for a number of times, suspended or dismissed which forced Nepali leaders to exile in India. It still continues in different ways. Nepal's political development is directly or indirectly influenced by political activism in India. India has been important 'space'for Nepal's political change and it also has been a place for migrant's political activism since a long time.

Out of several Nepali migrants' organizations in India, some are active in transnational political mobilizations. This study will look into the concept, evolution and contemporary discourse of the political transnationalism. It examines in the framework of transnationalism; development process of major political parties in Nepal, and situation of Nepali migrant's political activisms in India and their associations with homeland politics.
\end{abstract}

Definitions of migrant 'transnationalism' have flourished in the 1990s to explain the phenomena of migrants' activities in two or more countries. The back and forth relations of their home and host countries resembles this fact. Steven Vertovec (2009) defines the broad meaning of transnationalism refers to multiple ties and intersection linking people or institutions across the borders of nation states.

Migration has never been a one-way process of assimilation in multicultural field but it varies in degrees or it is embedded in the multiple sites and layers of the transnational social fields in which they live (Levitt and Jaworsky, 2007). They argue "decade ago international relations had to rethink its basic conceptual categories to capture cross-border relations between non-state actors and subnational actors." Several aspects of social life take place across border. Most of the works on migrant transnationalism has emphasized transnationalism as a "counter-narrative to assimilation theory" (Glick Schiler et al., 1992; Guarnizo and Portes, 2001). 
Migrant's multiple attachments in a political activism is a notion of 'homeland politics' and also sometimes described it in terms of 'long-distance nationalism', 'deterritorialized nations' or 'globalization of domestic politics' (Anderson, 1995, Basch et al., 1994; Koslowski 2001). Portes et al. (1999) suggest that this kind of transnationalism could be applied also in economic domain, where local level transnational business practices are relatively important. Similarly, transnational migrant communities connected with homeland politics are in a variety of forms. According to Ostergaard-Nielsen (2003), such practices are organizing return program for exiled groups, lobbying to homeland politics, extended offices of political parties, formation of migrant hometown associations, representing social and cultural groups of homeland, and opposition groups campaigning or planning actions to effect political changes in homeland. In fact, political activities of migrants in receiving country do not run in smooth way. Host country's policy towards sending country plays the vital role. Mostly, it determines by the power relation between two countries that effects migrants' political participation in destined country.

The range of transnational political activities of transnational migrants entails both nation building and nation wrecking. There are many examples of nationbuilding projects, which were not only designed but also operated from exile. Lenin, Gandhi, and Ho Chi Minh's periods in exile are some of the examples of this kind. These types of practices still continue. For example, several Kurds, Kashmiris, Sri Lankan, Tamils and Palestines are operating as 'stateless diasporas' so as to achieve their goal. In all forms of political transnationalism, homeland political allegiances, mobilization and engagements rest on the re-configuration of their identities. People from a particular place regard themselves as legitimate members of the collective identity and socio-political order of a place even though they reside outside the borders (Vertovec, 2009).

States are not natural entities rather than the products of complex social and historical processes. The state capacity, authority, structures, legitimacy, and sovereignty depend on the forces that participate in the process of state making (Riaz \& Basu, 2010). In the process of state making, those factors keep changing and causing new dynamics at different times under different circumstances. Therefore, there is no linear way of state formation process. In case of Nepal too, a process of nation-state formation has not developed in a linear way. The practice of liberal democratic political system in Nepal is relatively new and has been 
imperiled to many constitutional and political crises. Nepali people and liberal political parties of Nepal have struggled for democracy and multiparty system.

Before examining the situation of Nepali migrants and their activities in India and its linkages in Nepali politics, it would be worthwhile to briefly look into the geo-political aspect and its impact on the Nepali political and social change. This history of Nepal is linked up with the history of the central Himalayan region and that of Northern India. Before the formation of nation-states in South Asia, the movement of people was not hampered by national boundaries but was guided by different ideals and determined by different constraints. The existence of Nepalis in outside Nepal is only the result of long-term historical and social developments.

The History of outmigration of Nepalis was existed due to junction of trade between Tibet and India. Trans-Himalayan trade was the oldest phenomenon of movement of Nepali people from one place to another around 500 B.C. During the dynasties of 'Lichchhabi' and 'Malla' period in the era between $2^{\text {nd }}$ to $15^{\text {th }}$ century, Kathmandu valley was the hub of trans-border trade between India, Nepal, Tibet and China (Schrader, 1988). But, first time the wave of labor migration from Nepal began in 18th and 19th centuries when the state's oppressive land and labour policies forced peasants in the hills to move out of their land and seek their livelihoods elsewhere, both within Nepal and across the border into India (Regmi, 1978; Shrestha, 1985).

The treaty between Nepal and British India in 1816 opened the door to set up Gorkha regiments in British Indian army. However, till 1885, Nepal Government opposed the recruitment of the Nepalis by the British as Gorkha soldiers, widely known as 'Gorkha recruitment'. The government of Nepal's position to the 'Gorkha recruitment' was changed in 1886. But, after the accession of Bir Shamsher Rana to the prime-minister ship through a coup d'état, Nepal's government openly supported the British to hire Nepalis in British army (Shrestha, 1990; Thieme, 2006). The duly or unduly valorized Gorkha soldiers have recruited in foreign armies since the late 1800's, first by British India then the process was continued by independent India and more recently by the governments of Singapore and Brunei (Yamanaka, 2000).

"For a long time, Nepal's policy limited to service in the British or Indian army or to other jobs in India" (Thieme, 2006). The 'Gorkha recruitment' in India has been remained the primary form of foreign employment since at least for many decades. One of the reasons for this is there has not been much work opportunity 
in Nepal and it was nearly impossible to travel to other part of the world in the absence of foreign employment policy of the Government of Nepal.

Restoration of multiparty democracy in 1990 began the access to obtain travel documents and passports for commoner Nepalis. Till then, India was the only easily accessible destination for Nepali migrant worker, which still prevails to be the one.

In this way, Nepali migration to India has been an ongoing phenomenon with working diaspora spreading across India. Free and reciprocal movement of people through open border is facilitated by the Article VII of the 'Peace and Friendship Treaty of 1950' between Nepal and India. The Article states:

"The governments of India and Nepal agree to grant, on a reciprocal basis, to the nationals of one country in the territories of the other the same privileges in the matter of residence, ownership of property, participation of trade and commerce, movement and other privileges of a similar nature (Article VII, Treaty of Peace and Friendship, Kathmandu, July 31, 1950)'”.

The treaty itself is not explicit about open border system between Nepal and India but it only has an article related to migration. This article does not say equal treatment and employment opportunity to Nepali workers. It rather talks about the privileges in residence, ownership of property, participation in trade, and movements. It does not, however, clarify that what are other privileges of a similar nature. Consequently, the textual ambiguity has frequently caused problem in the implementation of treaty's provision, especially in the case of Nepali migrant workers' relation to Indian state (Prasain, 2010). One of the most known narratives of Nepali migration comes from Nepali youths who served in the army of the Sikh ruler, Ranjit Singh, in Lahore (now in Pakistan). In popular parlance, those who worked as armies in Lahore were known as 'Lahure'. This term got common recognition and is used to indicate all others who serve in any foreign lands as soldier. Even later, Nepali soldiers fighting as 'Gorkhas' in British and Indian regiments, still carry the label of 'Lahure' (KC, 2011). Later, 'Lahure' culture encompasses all most all kinds of jobs doing in abroad. It is now synonyms for all migrant workers.

There is a long history of establishing identity-based Nepali non-government organizations in India. In India, there are many organizations formed by Nepalis, 
they are working in the fields related to politics, cultures and economy of Nepal. Thakur Chandan Singh's All India Gorkha League, established in Deharadun in 1924, is an example in this regard. Likewise, Chhabilal Upadhyay, a Nepali speaking professional grazer of Assam fought for grazers' rights against tax increment and eviction of Nepali grazers from some reserves (Nag, 2003; Prasain, 2010). Dalbir Singh Lohar was another influential leader of the Indian National Congress (INC) in Assam among the Nepali speaking people. He was a member of the legislative assembly of Assam between 1946 and 1952, and again he was elected as INC-candidate in 1952 election (Upadhyay, 2003; Prasain, 2010). Even before, a number of Nepalis started getting involved in the Indian freedom struggle (Bhandari, 2003). During the Quit India Movement (QIM) in the beginning of $19^{\text {th }}$ century, most of the Indian leaders were educated in Britain and brought liberal democratic idea into India. Together with them, some youths from Nepal also participated in the QIM and gained a lot of political insights, which prepared them to act against the autocratic Rana regime of Nepal. One of the vivid examples of this can be seen in the background of veteran leaders of the contemporary Nepali politics. Most of the key leaders of the major political parties were either influenced by or involved in Indian Independence Movement (Bashyal, 2014).

Migration of people from Nepal to India, whether it is for army or civil employment, or for an education, has ultimately led to import of new political, cultural and economic values to Nepal. Thieme (2006) writes "the concern being that returning army servicemen would bring revolutionary ideas into Nepal". Those ex-army personnel, who returned to Nepal, were first exposed to the freedom movement of India, helped in bringing down the autocratic government of the Ranas. This political consciousness is important for Nepal. Many Gorkhas, after leaving the British Army, joined the ranks of Indian National Army of Subhash Chandra Bose. At the same time, Nepali intellectuals and others studying and working in India joined the freedom movement against 'British Raj'. For example, Man Mohan Adhikari and B. P. Koirala had joined the QIM. Despite Nepalis' contribution to the Indian independence movement, Nepali community in India were not assured of any minority rights as they were not recognized as a community in India. But they constituted one of the largest minority groups in India and have been living in the country for generations (Adhikari and Gurung, 2010). In the modern times, the Gorkha's role in the development of Nepali society and culture is difficult to compare to that of other Nepali migrants. Gorkha's service in other country's army deprived Nepal of its young human resources, 
especially during the wars. However, the Gorkha community has become a leader to nurturing pan-Nepalese identity, and at the same time has played a role in bringing western lifestyles and values to Nepali society (Uesugi, 2007).

\section{Overview of Nepali Organizations in India}

There is a long history of people of Nepali origin being organized in India. Gorkha army connection is prevalent initially and that was pivotal in building the organization. Migrant Nepalis and the Nepali speaking Indians were also the participants of the revolution of 1951 in Nepal. At that time, the identity distinction between migrant Nepali and Indian Nepali was not significant. Both considered Nepal as the land of their ancestors and there was a feeling that they should serve the motherland. The Indian Nepalis were involved in the revolution to obtain rights of Nepali as a part of India. There was dissociation of them being Nepali and a sort of dual Nepali identity evolved. There have been some attempts to organize Nepali migrants in India.

For the last 100 years, Nepalis have organizations in India- firstly, to fight against Rana Oligarchy ${ }^{1}$ and then for other political and social welfare purposes back in their own country. In 1959, Ek Dev Ale, an associate of Pushpalal Shrestha, one of the founders of Communist Party of Nepal (CPN), had established an Indiawide organization known as Akhil Bharat Prabasi Nepali Kalayankari Sangh (All India Immigrant Nepali Welfare Association). It was mainly concentrated in Calcutta and Uttar Pradesh.

At present, there are several migrant organizations in India but most of them are inactive and few are concentrated in social and cultural issues. Though some migrants' organizations are registered in Indian Society Act, they are linked to Nepal's political parties and their activities. Currently, the most active organizations in India are: the Immigrant Nepali Association, Bharat (INA) which is linked to Communist Party of Nepal (CPN-UML), the Mulpravah All India Nepali Unity Society (AINUS), linked to the CPN (Masaal), Nepali Jan Samparka Samiti, associated with Nepali Congress (NC) and All India Nepali Unity Society (AINUS) affiliated with Unified Communist Party of Nepal (Maoist) and recently formed Nepal Revolutionary Communist Party-Maoist. These organizations have their roles to play for the protection and promotion of migrant workers in India; however, their political role in India largely depends on the Nepali political

1 Rana oligarchy in Nepal continued for 104 years till 1950. 
scenario. During the period of Jana Andolan 2006 (people's movement), they actively participated, along with Nepali political leaders who were living in exile, in the people's movements at homeland and aboard.

During 30 years 'Panchayat era', India was a safe heaven and assembly spot for underground and exiled Nepali political leaders. CPN was founded in Kolkata and NC Leader Subarna Shamasher too resided there. Later, it shifted to Banaras, which remained the hub of Nepali politics for a long time. During 1960s, Banaras was the center for Nepali political, literary, socio-cultural and religious activities. It was more of political center of Nepali students. There were around 1000 students, out of whom majorities were in Banaras Hindu University and other Sanskrit study centers. Among Nepali students, the Banaras wing was highly active at that time. It was common competitive forum for all political schools of Nepal. Regular elections used to take place between the NC and different factions of CPN. There were various student organizations with political nature. In the beginning, Nepali Student Council (Nepali Chhatra Parishad) was a common platform for all the students. This particular organization was under the hold of communist parties until some of the NC affiliated youths including Pradeep Giri, Chakra Bastola and Bhagwat Gyawali won half of the seats in the election and broke the communist stronghold in 1965. According to Chakra Bastola, because of lack of majority in the elections, the communist affiliated students then decided to set up their own council ${ }^{2}$. It remained active till the end of 1976/77. Both NC and CPN indulged in competitive atmosphere during that period and the person winning the election would be assured of an established and prominent place in national politics of Nepal.

It has often been pointed out that Banaras has had a special importance for Nepal's history. During that time, central bureaus of most of the Nepal's political parties were located in Banaras, for instance, NC and CPN's central offices were existed over there. After 1990's political change in Nepal, they were converted to the office of Nepali students or migrants organizations. This change resulted because of two reasons as quoted by CPN-UML leader Shankar Pokhrel': "first, the development of CPN (ML)'s school during 'Jhapa Andolan' (in 1970s) decided to focus its operations inside the country, and secondly, in the next decade

2 Interview with Chakra Prasad Bastola, former Minister for Foreign Affairs of Nepal, in Delhi, January 2012

3 Interview with Shankar Pokhrel, in Kathmandu, December 2011 
$\mathrm{NC}$ decided to return home and operate inside the country in the name of 'national reconciliation'. After these developments, the Banaras-centric political operation became indirect activities through their sister wings like student and migrant organizations. Until 1990, the role of Banaras was significant in Nepali political development. Even in the 1990s people's movement, it played an important role"4 (Bastola, 2012). Banaras not only produced significant numbers of political activists for Nepal but also gave a platform for practicing democratic exercise in the political front.

In fact, at that time, many student organizations were existed in major student centers like Haridwar and Brindaban. The start of this tradition can be traced back to the exiled leaders where they did interact with the students for the input and continue political movements inside the country. Therefore, we can notice a rapid politicization of the student unions. The Nepali tradition of selecting political leaders through the student union elections expanded even to India among Nepali students' community. Post-60s political activities of students significantly increased all over India, particularly in the northern belt.

The student organizations were also directly involved with Nepal's political parties. Party members had close contacts with the student organizations. Political activities did take place majorly along the bordering areas among exiled leaders in India and underground members in Nepal. All political parties had strong student bases (before Banaras, parties used cities like Kolkata and Patna as their political bases). In 1980s, Panchayat Regime provided scholarship to some students under supervision of Bedananda Jha (The ambassador to India) and sent them to India to prepare as advocate for the regime. But, among them most of the students changed their political stance and joined anti-Panchayati camp. For example, Baburam Bhattarai joined communist party- CPN-Masaal and put his efforts to integrate it. In 1977, Bhattarai formed All India Nepalese Student Union. In the beginning, it was non-political but after discussion with Mohan Bikram Singh and other leaders of CPN-Masal, it started working together with the party's student wing in India. In India, student wings of Nepal's communist parties are more vibrant and active in organizing them. Shankar Pokhrel (2012) evaluates:

"Nepali congress's student's performance was weaker than other Communist parties. Communists were more organized and active at that time. There was huge thoughtful struggle, when I went to Banaras in the campaign to make All India-

4 Interview with Chakra Prasad Bastola, former foreign minister of Nepal, Delhi, January 2012 
Nepal Student Free Student Union (AINSFU). Earlier, it was common platform for all progressive students. Other groups monopolized it so it resulted in the boycott of conference held in Hissar and thus the formation of AINFSU in Faridabad in 1983. Later, it became the most popular and active student organization in India. A member of students could be classified as: Sanskrit students primarily from Haridwar, Brindavan, Ayodhya and Banaras, others were mostly from Banaras and Delhi. Under Colombo plan, the students were spread all over the country but the concentration was high in Roorkie, Kurukshetra, Chandigarh, Hissar and Dehradun. That time even students with medical, engineering, agriculture and forestry background were active in Nepali student's politics in India".

Another element is the formation of migrant worker politics and economic activities. Initially, the workers and the students worked together at the forefront in political activities. After the restoration of multiparty democracy in 1990, the emphasis has been shifted. The workers now had their own political parties to affiliate with. As a political institution, students' organizations became weaker than before.

Apart from political linkages Nepali migrant organizations have, there are several other organizations. They are established in many places of India such as Nepali Mahasangh in Mumbai and Gurgaon, Ekta Samaj in Punjab, Gorkha Samiti in Jharkhand, Janmukti Morcha in Haryana, Bhutpurba Gorkha Sainik in Ranchi, Brihat Guwahati Gaupalan Sanstha. Varieties of Nepali migrants' organizations exist also in Delhi, for instance- Gurung Samaj, Newar Samaj, Sudur Paschim Sampark Manch, Nepali Samaj Sewa Samiti, Pravashi Jan Kalyan Samiti, Help Mission Nepali, Lumbini Gautam Buddha Charitable Trust, and Shri Pashupati Sampark Manch among many. These organizations are basically confined in limited area, active in their identical basis. They organize mainly cultural programs.

Chakra Bastola informs that the NC had formed Jan Sampark Samiti (JSS) in 1976 during BP Koirala's visit to Bombay before the formation of party organization in India. Post 1990, I became the ambassador of India. I made this appeal to make JSS an all India movement rather than just based on Bombay. It was not my initiative but I encouraged it. Since then, the JSS became an all India initiative. What is seen now is although JSS is a Congress institution; the advantages have been reaped by others".

JSS cadres themselves realized that there is not a big impact but the simplest of democratic processes in the Indian states like municipal elections. Like other 
leftist leaders of Nepal, Bastola opposed open border system and argued the India had gained a lot from the open border. The Nepali side has proposed visa system only to be denied by the Indian state. He further says, there are positive and negative sides of India's role as a using political space of India and the involvement of India in Nepali politics has been its own national interest rather than the result of the good faith.

In case of Prabasi Sangh Nepal and other left inclined migrant associations, for the sustenance of their organization, the members organize 'Bhailo' and 'Deusi' and collect money. For central level conference, center fixes quota as per number of members. Likewise, state committee also fixes quota for city committee. Central committee meeting generally happens in every 6 months, state committee meets every 3 months and city committee meets monthly or once in 2 months. They are mostly dependent on migrants' levy and donations.

Though they are registered as a non-political organization, they are more focused on political activities. Their strategy of activities differs as per place and time. To some extent, they assist in other social and legal problems as well for Nepali migrants. Maoist insurgency in Nepal (1996-2006) also affected them. After 2002-03, it was difficult to be politically active for their parent party in Nepal. During the people's uprising against monarchy in Nepal, they agreed to join hand with all parties despite their several disagreements.

"Initially Nepalese coming to India were confined with works of domestic help, cooks, guards and coolies but now things have changed. Now people are entrepreneurs and work for big hotels. People run their own food stalls. Initially Nepalese worked in government sector as well but now it has minimized. Now people are much in entrepreneur sector and decent service sector as well. Things have changed to a much extent regarding working opportunities, capabilities and conditions for nonresident Nepalese" (Dhakal, 2012). This had a definite significance in the political development in Nepal in terms of raising political awareness.

The trouble the migrants face while crossing the border is gradually minimizing in recent days. The migrants who appear different than north Indians such as Mongolian-looking people face more trouble in India as they are perceived as 'real Nepali'. Far western people of Nepal realize that they are much cheated because of their lower lovel of awareness.

"Until and unless our political activities are not harmful to Indian state we are allowed to do political activism and form Unions. Till now we are allowed to 
form unions and be politically active because we have not harmed Indian interest. Maoists, Congress, and others parties have done as we do but in future I think we will not remain as a political union. We will only function and work as registered non-residents association. It will focus more on matters of nonresident Nepalis rather than political activities of Nepal. Almost all political parties of Nepal have structure like ours in India" (Dhakal, 2012).

According to Mulprabah, migrants are insulted in India. Many migrants are unorganized and are indulged in bad habits of gambling and drinking. Bringing them to organization is very difficult. Their organization has been tackling with many issues of Nepali migrants who are devoid of their wages or are forced to flesh trades. They also have to face murder cases sometime.

Currently, Mulpravah have 15-16 whole timers working for organization. They publish one monthly bulletin. Initially they used to circulate 'Haak' weekly newspaper, importing all the way from Nepal. But now they print it locally. Earlier the name of the organization was same as to Maoist sympathizer organization. When the Maoist organization was banned, in order to avoid confusion and smooth functioning, they decided to change the name.

Another migrant organization Akhil Bharat Nepal Manch supports the Maoist people's war. From the Indian state, there were no forced evictions of imprisonments but these were related to extracting information regarding whereabouts of Maoist leaders rather than the activities of the Samaj. However, Laxman Pant says pressures were felt during the time from the administration where they used to niggle and haggle lower level cadres and organization members, put psychological pressures on them. Certain cases have also been found where party members have been wrongfully evicted from their jobs. But this is negligible.

All major migrant organnizations want to be connect with Nepal Embassy, access to Nepali political leaders and popular among migrants. They are organizing cultural programs, sports competition and rescue to Nepali migrants. They have fundamental differences based on their political ideologies of Nepal's political parties. Left orgamization like Mulpravah is much active organization in India. The culture or way of dealing of political parties in Nepal with people in Nepal is resembles in India too. They are sending their representative in major conferences and programs in Nepal. In left parties, working abroad also counts it as political activisms. Madhes based organization is not active in India. 


\section{Conclusion}

Transnational perspective is a useful lens, which sees migrants' practices, relations and fields of belonging. The political aspects of transnational migration have been under-studied compared with social, cultural and economic activities. More so, political activities are confined within nation-states boundary. Transnational political activism of Nepali migrants in India is unique and different than other case studies. The consequences of those political activities are that they are connected to many Nepali migrants and have been aware of Nepal's political developments.

In fact, India has been one of the key spaces for designing Nepali political discourse, is always contested and negotiated by Nepali since many decades. In each and every resistance movement in Nepal, transnational Nepali migrants have played vital role to achieve the goal. Nepal's major political parties were established in India and they started to organize Nepali migrants and they even established offices in India. During ‘quit India' movement in 1940s, many Nepali youths participated also jailed in India. Gorkha connection was the milestone for disseminating political ideas to Nepal.

India is after all a key destination for Nepali migrants. Most of them are temporary and unskilled. They have not much time to be active in politics. Particularly, in Sunday or other holidays only, they can gather and meet with other Nepali fellows. During the interview, this study found that large numbers of migrants are aloof and unknown about political activities in Delhi. Irrespective of their claim, very few of them are involved in those activities. But, in festivals like Teej and Dashai programs those migrants also participates in a larger numbers.

It is interesting that India is the liberal democratic country but most of the active Nepali migrants are inclined towards left-politics. And they are performance better than other democratic parties. Until and unless Nepali migrant organizations do not hamper the Indian interests, they can be active in their political parties. Otherwise anytime we can be banned in India". This kind of fear also we can see of them.

In India, most of the migrants are lies in lower middle-class or working class background. At first they comes for cause for economy and later interested migrants join in an organization. Nepali migrant organizations are the only institutions that provide egalitarian space. One of the major roles of the migrant organizations is also to helping the needy migrant workers. When one needs the medical help or financial assistance, the organization comes forward to find the 
solution collectively. The members of the organizations feel safe from outsiders as they have backing of their organizations. The organization becomes a source of social and physical security, which is important in foreign lands.

The organization gives a sense of belonging and power, and connects its members to the Nepali community culturally and politically. It has empowered them making them politically updated and culturally sensible. Organizing sports and cultural programs, they try to bring the entire Nepali community closer to each other. These kinds of activities connect other Nepali migrants who are not active members of any organizations. For most of the Nepali political parties, India's Nepali migrants are productive citizens because they are not participating directly in the nation but contribute when they are in trouble. For few others, the migrant organization becomes a political card that would help them grab the political power in Nepal. In other way, India and its states, where Nepali migrants are working, is the virtual constituency of several political parties of Nepal.

\section{Endnotes}

Central Bureau of Statistics (2011), Government of Nepal, National Planning Commission Secretariat, Nepal Living Standards Survey: Main Findings Vol. 1 and 2, Kathmandu.

Central Bureau of Statistics (2011), Population Census of Nepal, Kathmandu, Nepal

Anderson, Benedict (1992a) The New World Disorder. New Left Review 193:313.

Anderson, Benedict (1992b) Long-distance Nationalism: World Capitalism and the Rise of Identity Politics. Wertheim Lecture: University of Amsterdam.

Basch, Linda, Nina Glick Schiller, Cristina Szanton Blanc (1994), Nations unbound: transnational projects, postcolonial predicaments, and deterritorialized nation-states. New York: Routledge.

Beck, U (2007), 'Beyond class and nations: Reframing social inequalities in a globalizing world', British Journal of Sociology 58(4): 679-705

Glick Schiller, Nina; Basch, Linda \& Blanc Szanton, Cristina (1992) Towards a transnational perspective on migration: race, class, ethnicity and nationalism reconsidered, New Work: New Yoork Academy of Scinces.

KC, Gaurav (2011), "The Outward Pull”, The Kathmandu Post, Published on April 13. <http://www.ekantipur.com/the-kathmandu-post/2011/04/13/oped/ the-outward-pull/220562.html> [Accessed on 2011 April 17] 
44 Journal of International Affairs Vol. 1, No. 1, 2016

Levitt, Peggy and Jaworsky, B. Nandya (2007), “Transnational Migration Studies: Past Developments and Future Trends", The Annual Review of Sociology, 2007.33:129-56

Østergaard-Nielsen, Eva (2003), 'The politics of migrants' transnational political practices', International Migration Review, 37 (3), 760-86.

Portes, A (2001), 'Introduction: The debates and significance of immigrant transnationalism', Global Networks I (3): 181-191

Portes, Alejandro (1999), "Conclusion: Towards a New World- the Origins and Effects of Transnational Activities". Ethical and Racial Studies, 22: 463477

Prasain, Dinesh (2010), Subaltern transnationalism, citizenship and identity: A case study among labor migrants from Nepal in a Delhi neighborhood, unpublished $\mathrm{Ph} \mathrm{D}$ Thesis, Jawaharlal Nehru University, New Delhi

Regmi, M C, (1978a). Land Tenure and Taxation in Nepal. Kathmandu: Ratna Pustak Bhandar. [Reprint of his earlier four-volume work under the same title published between 1963 and 1968 by the Institute of International Studies, University of California at Berkeley.]

Regmi, M C, (1978b). Thatched Huts and Stucco Palaces: Peasants and Landlords in 19th-Century Nepal. New Delhi: Vikas. Reprinted in 1999. New Delhi: Adroit Publishers. Translated into Japanese by Junko Hasumi and published in 1998. Tokyo: Akashi Shoten.

Regmi, M C, (1978c). Preliminary Notes on the Nature of the Gorkhali State and Administration. Regmi Research Series 10(11): 171-174.

Schrader, H. 1988, Trading Patterns in the Nepal Himalaya, Bielefelder Studien zur Entwicklungssoziologie, Vol 39, breitenbach, Saabrucken.

Seddon, David, Adhikari Jagannath and Gurung Ganesh (2002), "Foreign Labour Migration and the Remittance Economy of Nepal", Critical Asian Studies .Nepal

Seddon, David, Jagannath Adhikari, Ganesh Gurung (2001): The New Lahures: foreign employment and remittance economy of Nepal, Kathmandu: Institute of Development Studies

Thieme, S. (2006), Social Networks and Migration: Far West Nepali Migrants in Delhi. Culture, Society, Environment, 7, LIT Publishing House, Münster.

Usugi (2007), Reexamining Transnationalism from Below and Transnationalism from Above: British Gurkha's Life Strategies and the Brigade of Gurkhas' Employment Policies, Ishi et al (eds), Nepalis Inside and Outside Nepal, Manohar Publications, India.

Vertovec, Steven (2009), Transnationalism, Routledge Taylor and Francis Group, London and New York. 